\title{
Honey as a bioindicator of arsenic contamination due to volcanic and mining activities in Chile
}

\author{
José M. Bastías ${ }^{*}$, Philippe Jambon' ${ }^{1}$, Ociel Muñoz², Nimia Manquián², Patricia Bahamonde², \\ and Miguel Neira ${ }^{2}$
}

\begin{abstract}
The content of heavy metals in honey is indicative of natural or anthropogenic pollution and has therefore been proposed as a feasible bioindicator for arsenic contamination in different regions of Chile. Total arsenic ( $\mathrm{t}$-As) and inorganic As (i-As) concentrations were determined in 227 samples of honey harvested during the years 2007, 2008, and 2009 in the areas of San Pedro de Atacama, Atacama, Chiloé, and Futaleufú, with the last town located $156 \mathrm{~km}$ from the Chaitén Volcano (latest eruption in 2008). These analyses were conducted using an atomic absorption spectrophotometer coupled with a hydride generator. In the honey samples, the concentrations of t-As ranged from 2.2 to $171.9 \mu \mathrm{g} \mathrm{kg}^{-1}$, and the $\mathrm{i}-\mathrm{As}$ concentrations ranged from none detected (ND) to $24.6 \mu \mathrm{g} \mathrm{kg}^{-1}$, with the area of San Pedro de Atacama having the highest As concentrations. The samples of honey from Futaleufú showed higher As concentrations after the eruption of the Chaitén Volcano in 2008. This study demonstrates that As pollution in honey may originate from both natural and anthropogenic sources. The results indicate that it is appropriate to use honey as a bioindicator of environmental pollution. In addition, the consumption of the honey studied herein does not pose any health hazards to the consumer due to its As content.
\end{abstract}

Key words: Honey, bioindicator, total arsenic, inorganic arsenic, pollution.

\section{INTRODUCTION}

Honey from bees (Apis mellifera) has biological and therapeutic functions and can be used as a bioindicator of environmental pollution, especially soil, plant, and atmospheric pollution (Jones, 1987; Bromenshenk et al., 1991; Muñoz and Palmero, 2006). The general characteristics and fundamental composition of honey depend on its botanical and geographical origin (Fredes and Montenegro, 2006; Pisani et al., 2008). An important aspect of the quality of honey is the presence of metals, which is directly related to the chemical composition of the soils in areas where bees forage. Therefore, the content of heavy metals in honey is indicative of the contamination of nearby soils, caused by volcanic and/or hydrothermal activities and weather conditions, among others factors that pose a risk to human health (Hernández et al., 2005; Pawel, 2009). The presence of the toxic metals $\mathrm{Cd}$ and $\mathrm{Pb}$ in honey has been thoroughly studied (Bogdanov, 2006). The toxic compounds studied most often in honey are pesticides and antibiotics (Fredes and Montenegro, 2006).

${ }^{1}$ Universidad del Bío-Bío, Departamento de Ingeniería de Alimentos, Av. Andrés Bello s/n, Chillán, Chile.

*Corresponding author (jobastias@ubiobio.cl).

${ }^{2}$ Universidad Austral de Chile, Facultad de Ciencias Agrarias, Campus Isla Teja s/n, Valdivia, Chile.

Received: 14 September 2012.

Accepted: 26 February 2013

doi:10.4067/S0718-58392013000200010.
Among the most toxic elements present in nature is As. This element is widely distributed in nature, with the most important As minerals being pyrite, realgar, and orpiment, which are frequently found in $\mathrm{S}$ compounds and metals. The As concentrations found in soils are between 0.1 and $50 \mu \mathrm{g} \mathrm{g}^{-1}$, with a mean level between 5 and $6 \mu \mathrm{g} \mathrm{g}^{-1}$ (Vahter et al., 1995). However, the levels of As may be much higher in soils polluted by human activity. Arsenic can accumulate in soils as the result of the use of pesticides, the application of fertilizers and the burning of fossil fuels. Other As sources include industrial deposits and animal waste (Heikens, 2006). The level of As found in soils depends on the intensity of human activity, the distance from the pollution source and the dispersion pattern of the pollutants. A significant part of the As produced by anthropogenic activity worldwide is obtained as a by-product of $\mathrm{Cu}, \mathrm{Pb}, \mathrm{Co}$ and $\mathrm{Au}$ foundries. Gold minerals contain up to $11 \% \mathrm{As}$, whereas $\mathrm{Pb}$ and $\mathrm{Cu}$ minerals contain 2-3\% As (Nriagu, 1989).

It has been demonstrated that As exposure in humans may cause adverse health effects, including damage to several organ systems, such as cardiovascular, nervous, hepatic, respiratory, and gastrointestinal (Basu et al., 2001; Gebel, 2001; Kannan et al., 2001; Centeno et al., 2002; Abernathy et al., 2003; Caceres et al., 2005). The toxicity of As varies according to its chemical composition, with inorganic species being more toxic than organic species, and inorganic As has been classified as a human carcinogen (IARC, 1987). 
Several studies suggest that honey can be used as a bioindicator for the environmental pollution caused by anthropogenic activities (Sanz et al., 1995; Latorre et al., 1999; González Paramás et al., 2000; Golob et al., 2005; Pisani et al., 2008). However, studies using honey as a bioindicator of environmental pollution that relate anthropogenic activities and volcanic eruptions to the concentration of As have not been completed thus far.

The purpose of the present study was to determine the concentration of total and inorganic As in honey samples collected during the years 2007, 2008, and 2009 in different areas of Chile (Figure 1) and to confirm if this honey is a good bioindicator of natural and/or anthropogenic contamination. The first study area is located in the extreme north of the country, where the world's most arid desert (the Atacama Desert) is found, in the town of San Pedro de Atacama in the Antofagasta Region and Atacama, which is a part of the Copiapó and Vallenar area within the Atacama Region. These areas have a high level of mining activity. The second study area is located in the south of the country, in the town of Futaleufú. This area has mild, cold weather, with an annual rainfall of $3000 \mathrm{~mm}$. This area is close to the Chaitén Volcano, which had a significant eruption in 2008. The last location analyzed corresponds to the Isla Grande of Chiloé. This area is considered pristine, and the primary activities are aquaculture and family agriculture. This region has mild, rainy weather, with an average rainfall of 2500 to $4000 \mathrm{~mm}$.

\section{MATERIALS AND METHODS}

\section{Preparation of laboratory material}

To eliminate any substances that could have interfered with the results, all of the glass and plastic materials involved in the study were thoroughly cleaned and then immersed in nitric acid $10 \%(\mathrm{v} / \mathrm{v})$ for $24 \mathrm{~h}$, followed by flushings with deionized water $\left(18 \mathrm{M} \Omega \mathrm{cm}^{-1}\right)$ and air drying. The quality of all of the reagents used was analytical grade or

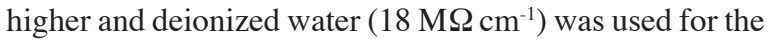
preparation of all solutions.

\section{Sample collection}

A total of 227 honey samples were analyzed: 84 samples from Atacama, 58 samples from San Pedro de Atacama, 28 samples from Futaleufú, and 57 samples from Chiloé. These samples were collected from January through March in 2007, 2008, and 2009. Each year, samples were collected from the same honeycombs. In 2009, volcanic ashes were collected from some apiaries from Futaleufú. The locations of the apiaries sampled in the different areas of the country are presented in Figure 1.

\section{Determination of total As (t-As)}

The analysis was performed by dry mineralization and quantification using an atomic absorption

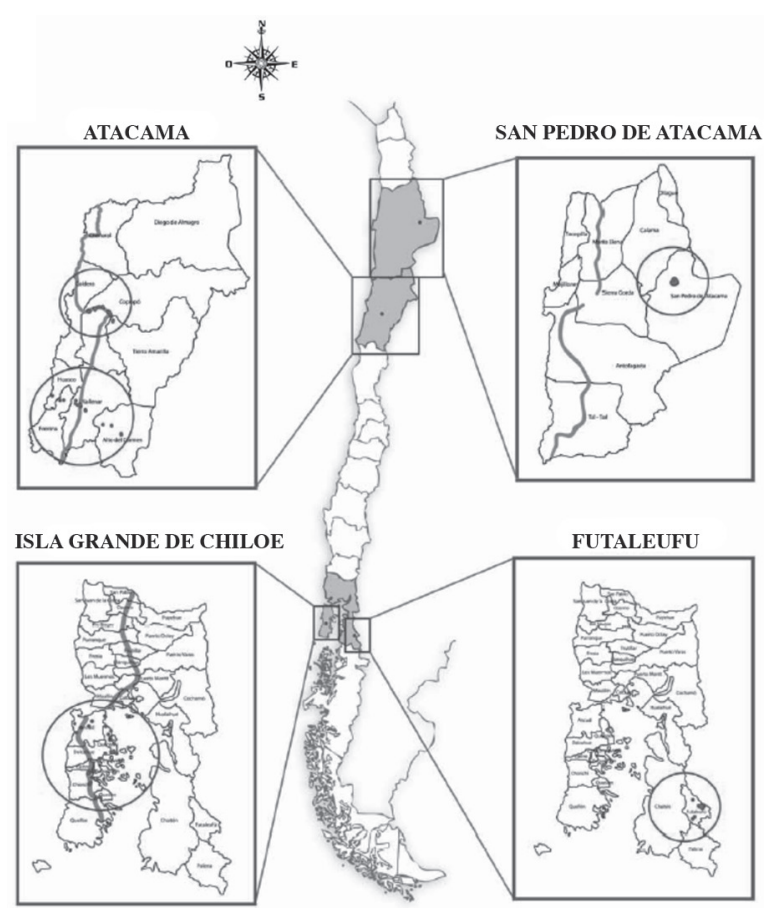

Figure 1. Locations of the four areas of Chile from which honey samples were collected. Red dots indicate the locations of the studied apiaries.

spectrophotometer (Varian, SpectrAA-55, Mulgrave, Victoria, Australia) coupled with a hydride generator (Muñoz et al., 2000). The samples (1 $\pm 0.001 \mathrm{~g})$ were treated with $5 \mathrm{~mL}$ of deionized water, $20 \mathrm{~mL}$ of concentrated $\mathrm{HNO}_{3}$, a mineralization agent $(1 \mathrm{~mL} \mathrm{MgO}$, $7.4 \%(\mathrm{w} / \mathrm{v})$ ) and $5 \mathrm{~mL}$ of $\mathrm{H}_{2} \mathrm{O}_{2}$. The liquid was evaporated by drying and mineralization at $450{ }^{\circ} \mathrm{C}$ with a gradual increase in temperature. The white ash was dissolved in $1 \mathrm{~mL}$ of deionized water and $1 \mathrm{~mL}$ of $\mathrm{HCl}$. This mixture was filtered (Whatman paper, $\mathrm{nr} 1$ ) and then diluted to 25 $\mathrm{mL}$ with $50 \% \mathrm{HCl}(\mathrm{v} / \mathrm{v})$. Prior to reading the results, a reducing mixture containing $5 \%$ ascorbic acid (w/v) and $5 \% \mathrm{KI}(\mathrm{w} / \mathrm{v})$ was added. The samples were analyzed in duplicate. The detection limit for t-As was $0.05 \mu \mathrm{g} \mathrm{kg}^{-1}$ wet weight.

\section{Determination of inorganic arsenic (i-As)}

The determination of i-As was performed by acid digestion, extraction with solvents and quantification using an atomic absorption spectrophotometer (Varian, SpectrAA-55, Mulgrave, Victoria, Australia) coupled with a hydride generator (Muñoz et al., 1999). Deionized water $(4.1 \mathrm{~mL})$ was added to the samples $(1 \pm 0.001 \mathrm{~g})$ along with $18.4 \mathrm{~mL}$ of concentrated $\mathrm{HCl}$. The mixture was incubated overnight and then reduced with $\mathrm{HBr}(2$ $\mathrm{mL})$ and hydrazine sulfate $(1.5 \% \mathrm{w} / \mathrm{v}, 1 \mathrm{~mL})$. The $\mathrm{i}-\mathrm{As}$ was extracted with chloroform $(3 \times 10 \mathrm{~mL})$, and the chloroform was retro-extracted with $1 \mathrm{~mol} \mathrm{~L}^{-1} \mathrm{HCl}(2 \times 10$ $\mathrm{mL})$. The retro-extraction phase was then dry-mineralized 
by adding $10 \mathrm{~mL}$ of concentrated $\mathrm{HNO}_{3}$ and $2.5 \mathrm{~mL} \mathrm{MgO}$ $(7.4 \% \mathrm{w} / \mathrm{v})$. The mixture was then dried, and the samples were treated as described for t-As. The samples were analyzed in duplicate. The detection limit for i-As was $0.075 \mu \mathrm{g} \mathrm{kg}^{-1}$ wet weight (w/w).

\section{Statistical analyses}

The t-As and i-As concentrations in the apiaries from several regions over the 3-yr period were analyzed using descriptive statistics (media and standard deviation) and an ANOVA at a 95\% confidence level using the statistical software Statgraphics® Plus 5.1.

\section{RESULTS AND DISCUSSION}

\section{Total arsenic}

Figure 2 shows the results for t-As concentrations found in honey samples collected in different years from different areas of Chile. The concentrations ranged from $2.27 \mu \mathrm{g} \mathrm{kg}^{-1}$ in one 2009 sample from Chiloé to 171.9 $\mu \mathrm{g} \mathrm{kg}^{-1}$ in one 2007 sample from San Pedro de Atacama. The samples from San Pedro de Atacama had the highest concentrations of t-As, whereas the lowest concentrations were found in the Chiloé samples.

There was significant variability in t-As concentrations in honey samples collected during the same year from different areas of Chile (Figure 1). This variability is associated with the location of the apiaries found in different places within the same research area. Thus, the concentration of environmental As may vary because the As may originate from sources such as soil erosion, volcanic eruption, and human activity, among other sources (Del Razo et al., 2004). In particular, the largest concentrations found in San Pedro de Atacama may be associated with the Antofagasta Region, which is the primary mining production region in Chile, and previous

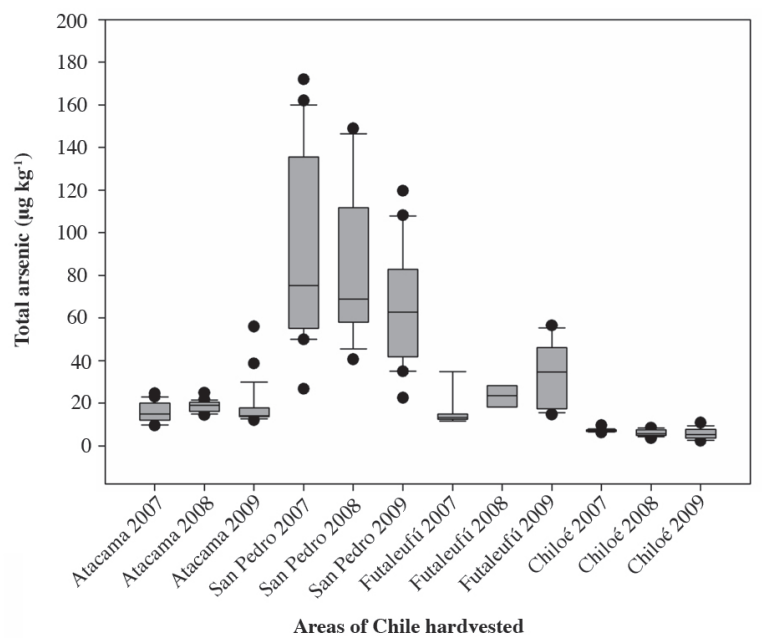

Figure 2. Concentrations of total arsenic in the different honey samples from the four locations of Chile that were harvested during the years 2007, 2008, and 2009. studies have confirmed high As concentrations in the environment and in vegetables from this region (Smith et al., 2000; Queirolo et al., 2000; Muñoz et al., 2002; Romero et al., 2003).

When analyzing the average t-As concentrations in honey samples from each of the areas studied, it was determined that in Atacama there was no significant difference for the 3 years studied. In the cases of San Pedro de Atacama and Futaleufú, t-As concentrations were significantly higher in 2009, whereas in Chiloé t-As concentration was significantly higher in 2007 , even though t-As concentrations were much lower than those of the other areas (Figure 2). The variability for the As concentration in a particular area may be associated with different factors. In the case of San Pedro de Atacama, the variability could be due to mining exploitation, and for Chiloé it could be the result of the typical variability of soils. For Futaleufú, the significant high difference observed for 2009 is most likely attributable to the eruption of the Chaitén Volcano in May 2008.

Comparisons of the average $\mathrm{t}$-As concentrations found in the honey samples for each year analyzed (Figure 3) revealed that the samples from San Pedro de Atacama showed higher concentrations of t-As in each of the years studied, differing from the Chiloé samples, which had lower t-As concentrations in those same years. The above results can be associated with the fact that honey samples from San Pedro come from the Antofagasta Region, where mining is the primary activity. In contrast, the primary activities in Chiloé are aquiculture and family agriculture, which lead to little pollution of the environment, especially with respect to As, and these are the reasons why Chiloé is known as an agro-ecological territory (INE, 2008; SERNAGEOMIN, 2009; Venegas, 2009). It is widely known that the dust from open-pit mining and the fumes from $\mathrm{Cu}$ foundries may spread over several kilometers. This dust and these fumes can

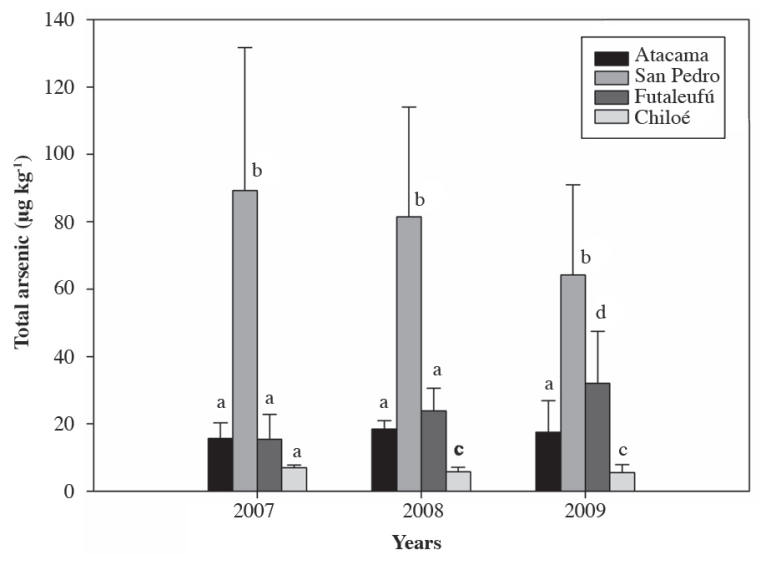

Figure 3. Mean concentrations of total arsenic in the honey samples according to the harvest year in the different areas of Chile. Different letters over the bars indicate differences according to Tukey's test (P $<0.05)$. 
lead to As contamination because they can come into direct contact with honeycombs or deposit pollutants on flowers and in the soil (Krunic, 1989). However, for the years 2007 and 2008, there were no significant differences between honey samples from Atacama and Futaleufú with respect to t-As concentrations. These findings are particularly interesting given that these samples came from the north and the south of the country, respectively, which are areas with completely different geographic and weather conditions.

For the year 2009, As levels for all of the areas studied were significantly different (Figure 3). Specifically, the average concentration in Futaleufú honey samples increased to $32.15 \mu \mathrm{g} \mathrm{kg}^{-1}$. This high concentration was surpassed only by the samples from San Pedro de Atacama $\left(64.25 \mu \mathrm{g} \mathrm{kg}^{-1}\right)$, and the high concentration in this area may be the result of natural pollution caused by the eruption of the Chaitén Volcano (May 2008). This fact would confirm the hypothesis of several authors that one natural source of As is volcanic eruptions (Robock, 2000; Del Razo et al., 2004; Aiuppa et al., 2006).

The As concentrations in honey samples reported in previous studies vary and only address t-As. FellerDemalsy et al. (1989) analyzed honey samples of different geographical origins in Canada and found concentrations of t-As ranging from 0.0 to $140 \mu \mathrm{g} \mathrm{kg}^{-1}$. These values are very close to those found in the present study. Krunić et al. (1989) analyzed honey samples from an area close to a $\mathrm{Cu}$ refinery and found $\mathrm{t}-\mathrm{As}$ concentrations that ranged from 28 to $67 \mu \mathrm{g} \mathrm{kg}^{-1}$, similar to the concentrations found in honey samples from San Pedro de Atacama. In contrast, Ajtony et al. (2007) analyzed honey from different regions in Hungary and found t-As concentrations from 0.0 to 7.2 $\mu \mathrm{g} \mathrm{kg}^{-1}$, similar to the $\mathrm{t}$-As concentrations in the honey samples from Chiloé. A recent study on honey from Siena County (Italy), which is an area considered to be relatively free of industrial pollution because its main activity is agriculture, revealed that its $\mathrm{t}$-As concentrations varied from 2.7 to $20.2 \mu \mathrm{g} \mathrm{kg}^{-1}$ (Pisani et al., 2008). The above results confirm that the presence of As in honey may come from different origins, both natural and anthropogenic.

Currently, at the international level, the standard for the maximum As concentration in honey is not clear, and only MERCOSUR has established a maximum tolerance limit of $1.0 \mathrm{mg} \mathrm{kg}^{-1}$ (MERCOSUR, 1994). The Reglamento Sanitario de los Alimentos (RSA) (Food Sanitary Regulation) of Chile has not established a maximum allowable concentration of As in honey but does specify maximum levels for nectar and fruit juice (0.2 $\left.\mathrm{mg} \mathrm{kg}^{-1}\right)$; glucose, lactose, and fructose syrup (1.0 $\mathrm{mg} \mathrm{kg}^{-1}$ ); and other substances (MINSAL, 2008). These concentrations may be used as parameters for honey. The highest concentration of $\mathrm{t}$-As from this study, found in a honey sample from San Pedro de Atacama in the year 2007 (171.9 $\left.\mu \mathrm{g} \mathrm{kg}^{-1}\right)$, is below the concentrations established for fruit nectar by the RSA and MERCOSUR. Therefore, all of the honey samples analyzed in the present study meet the current standard.

\section{Inorganic arsenic}

Figure 4 shows i-As concentrations in honey samples for different years and areas of Chile. The values found range from not detected (ND) (for one 2007 sample from Chiloé) to $24.65 \mu \mathrm{g} \mathrm{kg}^{-1}$ (for one 2008 sample from San Pedro de Atacama). In regard to t-As, the highest i-As concentration was found in honey samples from San Pedro de Atacama, with the year 2008 having the highest average t-As concentration $\left(18.11 \mu \mathrm{g} \mathrm{kg}^{-1}\right)$. Samples from Chiloé had the lowest average concentrations during 2009 $\left(2.76 \mu \mathrm{g} \mathrm{kg}^{-1}\right)$. The honey sample with the highest i-As content was a 2009 sample from Futaleufú, with $28.78 \mu \mathrm{g}$ i-As $\mathrm{kg}^{-1}$, accounting for $51.1 \%$ of $\mathrm{t}-\mathrm{As}$. This result was unexpected because the highest $\mathrm{t}$-As concentrations were found in honey samples from San Pedro de Atacama. However, when analyzing the samples from this location, the sample with the highest i-As concentration was from 2008 , with $24.65 \mu \mathrm{g}$ i-As $\mathrm{kg}^{-1}$, accounting for only $20.1 \%$ of t-As.

The analysis results of $\mathrm{i}$-As concentrations in honey samples from different locations by year are presented in Figure 5. For 2007, there were no significant differences among the samples from Futaleufú and Chiloé. During 2007 and 2008, the largest differences and highest i-As concentrations were found in honey samples from San Pedro de Atacama. However, in 2009, i-As concentrations increased dramatically in honey samples from Futaleufú, reaching concentrations similar to those from San Pedro de Atacama.

The largest proportions of i-As in the 2009 honey samples from Futaleufú were associated with the eruption of the Chaitén Volcano. The amount of As due to the eruption was confirmed through the analysis of ashes

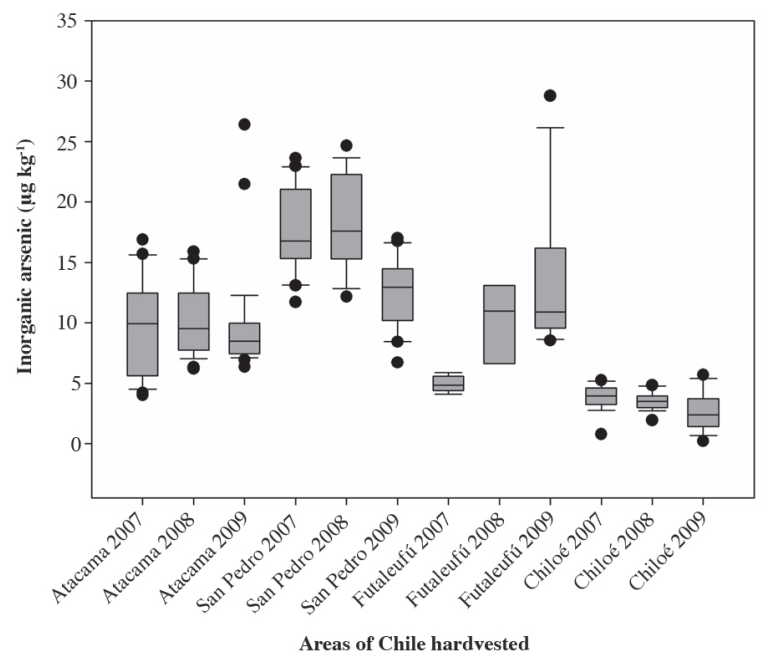

Figure 4. Concentrations of total arsenic in different honey samples from the four locations of Chile harvested during the years 2007, 2008 , and 2009. 


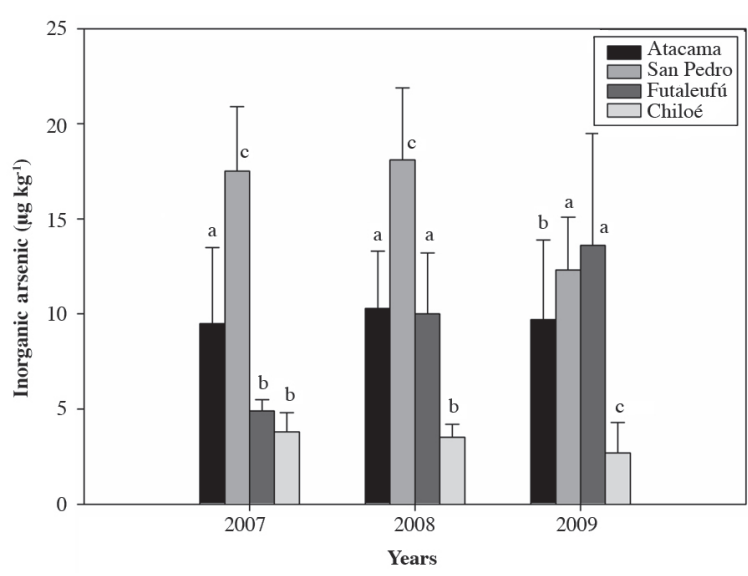

Figure 5. Mean concentrations of inorganic arsenic in honey samples according to the harvest year in the different areas of Chile. Different letters over the bars indicate differences according to Tukey's test $(P$ $<0.05)$.

collected during the honey sample collection in 2009 . These concentrations ranged from 1200 to $12930 \mu \mathrm{g}$ t-As $\mathrm{kg}^{-1}$ and from 960 to $10040 \mu \mathrm{g}$ i-As kg-1, with the i-As in all of the samples accounting for more than $75 \%$ of the t-As (Table 1), confirming that volcanic eruptions are a natural source of As (Robock, 2000; Aiuppa et al., 2006).

The results of the present study for the concentration of i-As in honey cannot be compared with previous results because there is currently no other work in the scientific literature that has analyzed the i-As concentration in honey. The concentrations of different species of As (organic and inorganic) in food vary widely. For example, in animals, particularly sea animals, organic As predominates, with i-As accounting for less than $6.9 \%$ of the t-As (Muñoz et al., 2000). For vegetables, the variability is more significant, and the proportion of i-As can range from 10 to $90 \%$ (Heikens, 2006; TorresEscribano et al., 2008). A recent study on student nutrition in Chile demonstrated that i-As contents ranged from 22.4 to $75.4 \%$ (Bastías et al., 2010). In the honey samples that we analyzed, i-As percentages in the different areas and from different years ranged from 19.3 to $60.2 \%$ (Table 2). Similar results have been found in vegetables and food products. The explanation for these results may be that the honey samples are of different origins.

Most relevant legislation refers to t-As and not to i-As; however, it must be taken into consideration that the

Table 1. Concentrations of total (t-As) and inorganic (i-As) arsenic and the average $\mathrm{i}$-As concentrations in the ash samples collected in Futaleufú in 2009.

\begin{tabular}{llcc}
\hline Sample $\mathrm{nr}$ & \multicolumn{1}{c}{$\mathrm{t}$-As } & $\mathrm{i}$-As & $\% \mathrm{i}$-As \\
\cline { 2 - 3 } 1 & $1910 \pm 23$ & $\mu \mathrm{g} \mathrm{kg}^{-1}$ & \\
2 & $1561 \pm 23$ & $1431 \pm 5$ & 75.00 \\
3 & $3271 \pm 8$ & $1180 \pm 3$ & 75.62 \\
4 & $1200 \pm 41$ & $2441 \pm 9$ & 74.62 \\
5 & $3720 \pm 46$ & $960 \pm 2$ & 80.00 \\
6 & $8890 \pm 19$ & $2860 \pm 21$ & 76.88 \\
7 & $12930 \pm 38$ & $8730 \pm 23$ & 98.20 \\
\hline
\end{tabular}

Table 2. Average of the inorganic arsenic (i-As) concentrations in the honey samples from the four areas of Chile for the 3 years studied.

\begin{tabular}{llc}
\hline Locality & Year & $\%$ i-As \\
\hline San Pedro de Atacama & 2007 & 19.7 \\
& 2008 & 22.3 \\
& 2009 & 19.3 \\
Atacama & 2007 & 60.2 \\
& 2008 & 55.7 \\
Futaleufú & 2009 & 55.0 \\
& 2007 & 31.7 \\
Chiloé & 2008 & 42.1 \\
& 2009 & 42.5 \\
& 2007 & 53.5 \\
& 2008 & 59.4 \\
\end{tabular}

most toxic forms of As are its inorganic species. Based on this fact, in 2005, the Ministry of Health in China established maximum limits for i-As in food products, ranging from $0.05 \mathrm{mg} \mathrm{kg}^{-1}$ in vegetables and fruits to 1.5 $\mathrm{mg} \mathrm{kg}^{-1}$ in weeds (Heikens, 2006). Specifically, in Chile, the RSA establishes limits for i-As only for crustaceans and shellfish, and this limit is $2.0 \mathrm{mg} \mathrm{kg}^{-1}$ (MINSAL, 2008). Based on the above criteria, limits established for vegetables and fruits by China can be used as a reference for honey. The highest i-As concentration, found in a 2009 sample (nr 8 from Futaleufú, $28.78 \mu \mathrm{g} \mathrm{kg}^{-1}$ ), was below this limit.

\section{Honey as a bioindicator}

Figure 2 illustrates that the highest concentrations of t-As during the $3 \mathrm{yr}$ of study came from honey samples from San Pedro de Atacama, an area of Chile with a significant amount of mining activity, followed by the honey samples from Futaleufú in 2009 (after the eruption of the Chaitén volcano). This same result can be observed in Figure 4 for i-As concentrations in the honey. These results confirm, as suggested by other authors (Sanz et al., 1995; Latorre et al., 1999; González Paramás et al., 2000; Golob et al., 2005; Pisani et al., 2008), that honey is a good biomarker of anthropogenic or natural pollution.

\section{Ingestion and health considerations}

There is currently no clear legislation regarding limits for total and i-As in honey. Thus, in the present study, $\mathrm{t}$-As and i-As concentrations in honey had to be compared to the limits for other food products. With respect to the intake of As in food products, in 1989, the Provisional Tolerable Daily Intake (PTDI) was established setting the limit for i-As ingestion to $2.1 \mu \mathrm{g} \mathrm{kg}^{-1}$ body weight per day (WHO, 1989). The PTDI for i-As for a person weighing $68 \mathrm{~kg}$ would be $142.8 \mu \mathrm{g} \mathrm{d}^{-1}$, whereas for a child weighing $20 \mathrm{~kg}$, the PTDI would be $42 \mu \mathrm{g} \mathrm{d}^{-1}$. If the $\mathrm{i}$-As concentration in honey is assumed to be the highest concentration ( $28.78 \mu \mathrm{g} \mathrm{kg}^{-1}$ for i-As) found in this study, an adult would need to consume $5.0 \mathrm{~kg}$ of honey per day to achieve the PTDI, and a child would have to consume $1.5 \mathrm{~kg}$. These amounts of honey would never be consumed 
based on standard honey consumption by humans, and thus, the honey samples that we studied can be considered safe for consumption with respect to As contents.

\section{CONCLUSIONS}

We have confirmed that honey is a good bioindicator of environmental pollution. The As pollution in the honey samples from the present study came predominantly from natural (volcanic eruption) and anthropogenic (mining) activities. The total As and inorganic As concentrations in the honey samples in this study do not pose a risk to human health because these levels are below the PTDI.

\section{ACKNOWLEDGEMENTS}

We would like to thank Universidad del Bío-Bío, Chile, and Servicio Agrícola y Ganadero (SAG), Ministerio de Agricultura, Chile, for the resources provided for the development of this study.

\section{LITERATURE CITED}

Abernathy, C.O., D.J. Thomas, and R.L. Calderon. 2003. Health effects and risk assessment of arsenic. Journal of Nutrition 133:1536S-1538S

Aiuppa, A., R. Avino, L. Brusca, S. Caliro, G. Chiodini, W. D'Alessandro, et al. 2006. Mineral control of arsenic content in thermal waters from volcano-hosted hydrothermal systems: Insights from island of Ischia and Phlegrean Fields (Campanian Volcanic Province, Italy). Chemical Geology 229:313-330.

Ajtony, Z., L. Bencs, R. Haraszi, J. Szigeti, and N. Szoboszlai. 2007. Study on the simultaneous determination of some essential and toxic trace elements in honey by multi-element graphite furnace atomic absorption spectrometry. Talanta 71:683-690.

Bastías, J.M., M. Bermúdez, J. Carrasco, O. Espinoza, M. Muñoz, M.J. Galotto, and O. Muñoz, 2010. Determination of dietary intake of total arsenic, inorganic arsenic and total mercury in the Chilean School Meal Program. Food Science and Technology International 16:443-450.

Basu, A., J. Mahata, S. Gupta, and A.K. Giri. 2001. Genetic toxicology of a paradoxical human carcinogen, arsenic: A review. Mutation Research 488:171-194.

Bogdanov, S. 2006. Contaminants of bee products. Apidologie 37:118.

Bromenshenk, J.J., J.L. Gudatis, S.R. Carlson, J.M. Thomas, and M.A. Simmons. 1991. Population dynamics of honey bee nucleus colonies exposed to industrial pollutants. Apidologie 22:359-369.

Caceres, D., P. Pino, N. Montesinos, E. Atalah, H. Amigo, and D. Loomis. 2005. Exposure to inorganic arsenic in drinking water and total urinary arsenic concentration in a Chilean population. Environmental Research 98:151-159.

Centeno, J.A., F.G. Mullick, L. Martinez, N.P. Page, H. Gibb, D. Longfellow, et al. 2002. Pathology related to chronic arsenic exposure. Environmental Health Perspectives 110(Suppl. 5):883886.

Del Razo, L.M., B. Quintanilla-Vega, y A. Albores. 2004. Arsénico. In Albert. L.A. (ed.) Toxicología ambiental. 453 p. Universidad Autónoma de Ciudad Juárez, México.

Feller-Demalsy, M.J., B. Vincent, et F. Beaulieu. 1989. Teneur en mineraux et origine geographique des miels du Canada. Apidologie 20:77-91.

Fredes, C., and G. Montenegro. 2006. Heavy metals and other trace elements contents in Chilean honey. Ciencia e Investigación Agraria 33:50-58.
Gebel,T.W.2001.Genotoxicity of arsenical compounds. International Journal of Hygiene and Environmental Health 203:249-262.

Golob, T., U. Dobersěk, P. Kump, and M. Necěmer. 2005. Determination of trace and minor elements in Slovenian honey by total reflection X-ray fluorescence spectroscopy. Food Chemistry 91:593-600.

Heikens, A. 2006. Arsenic contamination of irrigation water, soil and crops in Bangladesh: Risk implications for sustainable agriculture and food safety is Asia. FAO-RAP 2006/20. Food and Agricultural Organization (FAO), Rome, Italy.

Hernández, O.M., J.M.G. Fraga, A.I. Jiménez, F. Jiménez, and J.J. Arias. 2005. Characterization of honey from the Canary Islands: determination of the mineral content by atomic absorption spectrophotometry. Food Chemistry 93:449-458.

IARC. 1987. Arsenic. p. 100-106. In IARC Monographs on the evaluation of carcinogenic risks to humans. Supplement 7. Overall evaluations of carcinogenicity: An updating of IARC Monographs 1 to 42. International Agency for Research on Cancer (IARC), Lion, France.

INE. 2008. Compendio estadístico. Instituto Nacional de Estadísticas (INE), Santiago, Chile.

Jones, K.C. 1987. Honey as an indicator of heavy-metal contamination. Water Air and Soil Pollution 33(1-2):179-189.

Kannan, G.M., N. Tripathi, S.N. Dube, M. Gupta, and S.J. Flora. 2001. Toxic effects of arsenic (III) on some hematopoietic and central nervous system variables in rats and guinea pigs. Journal of Toxicology - Clinical Toxicology 39:675-682.

Krunić, M.D., L.D. Terzić, and J.M. Kulinćervić. 1989. Honey resistance to air contamination with arsenic from a copper processing plant. Apidologie 20:251-255.

Latorre, M.J., R. Peña, C. Pita, A. Botana, S. García, and C. Herrero. 1999. Chemometric classification of honeys according to their type. II. Metal content data. Food Chemistry 66:263-268.

MERCOSUR. 1994. Límites máximos de tolerancia para contaminantes inorgánicos. MERCOSUR/GMC/Resolución $\mathrm{N}^{\circ}$ $102 / 94$.

MINSAL. 2008. Reglamento Sanitario de los Alimentos. Dto. ${ }^{\circ}$ 977/96 (D.Of. 13.05.97). República de Chile, Ministerio de Salud, Santiago, Chile.

Muñoz, O., V. Devesa, M.A. Súñer, D. Vélez, R. Montoro, I. Urieta, et al. 2000. Total and inorganic arsenic in fresh and processed fish products. Journal of Agricultural and Food Chemistry 48:43694376.

Muñoz, O., O. Diaz, I. Leyton, N. Nuñez, V. Devesa, M. Súñer, et al. 2002. Vegetables collected in the cultivated Andean Area of Northern Chile: Total and inorganic arsenic contents in raw vegetables. Journal of Agricultural and Food Chemistry 50:642647.

Muñoz, E., and S. Palmero. 2006. Determination of heavy metals in honey by potentiometric stripping analysis and using a continuous flow methodology. Food Chemistry 94:478-483.

Muñoz, O., D. Vélez, and R. Montoro. 1999. Optimization of the solubilization, extraction and determination of inorganic arsenic $[\mathrm{As}(\mathrm{iii})+\mathrm{As}(\mathrm{v})]$ in seafood products by acid digestion, solvent extraction and hydride generation atomic absorption spectrometry. The Analyst 124:601-607.

Nriagu, J.O. 1989. A global assessment of natural sources of atmospheric trace metals. Nature 338:47-49.

González Paramás, A.M.G., J.A. Gómez Bárez, R.J. GarciaVillanova, T. Rivas Palá, R. Ardanuy Albajar, and J. Sánchez Sánchez. 2000. Geographical discrimination of honeys by using mineral composition and common chemical quality parameters. Journal of the Science of Food and Agriculture 80:157-165.

Pawel, P. 2009. Determination of metal contentin honey by atomic absorptionand emission spectrometries. Trends in Analytical Chemistry 28:117-128.

Pisani, A., G. Protano, and F. Riccobono. 2008. Minor and trace elements in different honey types produced in Siena County (Italy). Food Chemistry 107:1553-1560. 
Queirolo, F., S. Stegen, M. Restovic, M. Paz, P. Ostapczuk, M.J. Schwuger, and L. Muñoz. 2000. Total arsenic, lead, and cadmium levels in vegetables cultivated at the Andean villages of northern Chile. Science of the Total Environment 255:75-84.

Robock, A. 2000. Volcanic eruptions and climate. Reviews of Geophysics 38:191-219.

Romero, L., H. Alonso, P. Campano, L. Fanfani, R. Cidu, C. Dadea, et al. 2003. Arsenic enrichment in waters and sediments of the Rio Loa (Second Region, Chile). Applied Geochemistry 18:13991416.

Sanz, S., C. Perez, A. Herrera, M. Sanz, and T. Juan. 1995. Application of a statistical approach to the classification of honey by geographical origin. Journal of the Science of Food and Agriculture 69:135-140.

SERNAGEOMIN. 2009. Anuario de la minería chilena. 145 p. Servicio Nacional de Geología y Minería (SERNAGEOMIN), Santiago, Chile.

Smith, AH., A.P. Arroyo, D.N. Mazumder, M.J. Kosnett, A.L. Hernandez, M. Beeris, et al. 2000. Arsenic-induced skin lesions among Atacameño people in Northern Chile despite good nutrition and centuries of exposure. Environmental Health Perspectives 108:617-620
Torres-Escribano, S., M. Lela, D. Vélez, and R. Montoro. 2008. Total and inorganic arsenic concentrations in rice sold in Spain, effect of cooking, and risk assessments. Environmental Science \& Technology 42:3867-3872.

Vahter, M., G. Concha, B. Nermell, R. Nilsson, F. Dulout, and A.T. Natarajan. 1995. A unique metabolism of inorganic arsenic in native Andean women. European Journal of Pharmacology: Environmental Toxicology and Pharmacology 293:454-462.

Venegas, C. 2009. Territorios agroecológicos con identidad cultural: la experiencia de Chiloé. Proyecto Desarrollo Territorial Rural con Identidad Cultural (DTR-IC). Rimisp, Santiago, Chile.

WHO. 1989. Evaluation of certain food additives and contaminants: $33^{\text {rd }}$ report of the Joint FAO/WHO Expert Committee on Food Additives; WHO Technical Report Series 759. World Health Organization (WHO), Geneva, Italy. 